Research Article

\title{
Comparison of Nesting Features and Breeding Success of Turtle Dove Streptopelia turtur between Orchards and Riparian Habitats
}

\author{
Ismail Mansouri $\mathbb{D}^{1},{ }^{1}$ Wafae Squalli $\mathbb{D}^{1},{ }^{1}$ Abdelbari El Agy $\mathbb{D D}^{1}{ }^{1}$ Abderahim El-Hassani, \\ Lahcen El Ghadraoui, ${ }^{1}$ and Mohamed Dakki (iD ${ }^{2}$ \\ ${ }^{1}$ Laboratory of Functional Ecology and Genie of Environment, Faculty of Sciences and Technology, USMBA, Fez, Morocco \\ ${ }^{2}$ Geo-biodiversity and Natural Patrimony Laboratory, Scientific Institute, Mohammed V University in Rabat, Morocco, \\ Rabat 10106, Morocco
}

Correspondence should be addressed to Ismail Mansouri; mankhori@gmail.com

Received 29 January 2021; Revised 21 March 2021; Accepted 29 March 2021; Published 8 April 2021

Academic Editor: Marco Cucco

Copyright (c) 2021 Ismail Mansouri et al. This is an open access article distributed under the Creative Commons Attribution License, which permits unrestricted use, distribution, and reproduction in any medium, provided the original work is properly cited.

\begin{abstract}
The European turtle dove Streptopelia turtur breeds in both farmlands and woodlands, and it is important to explore the difference in breeding ecology of this threatened game in these two ecosystem types. This study, carried out during four years (2015-2018), compares nesting features of this species and its breeding success between apple orchards and riparian vegetation in Midelt Province, Morocco. The main result revealed that the nest placement, including nesting-tree height and nest height, is similar between orchards and riparian trees. However, the nest dimensions (big and small diameters) were larger in orchards. Correlations were variable among nest placement parameters and dimensions. On the contrary, in four breeding seasons, where 566 nests were monitored (467 in orchards and 99 in riparian sites), the average breeding success was different (57\% of chicks in apple farms and 53\% in riparian vegetation). Moreover, in apple orchards, clutches' failure is due to both predation (18.89\% of eggs and $10.54 \%$ of chicks) and temperature lowering (5.03\% of unhatched eggs and $5.49 \%$ of dead chicks), while in riparian vegetation, the loss is due to nest desertion ( $21.33 \%$ of clutches) and mostly predation (33.16\% of clutches).
\end{abstract}

\section{Introduction}

The European turtle dove Streptopelia turtur is among birds that have dramatically declined in Europe $(-78 \%$ in Britain between 1980 and 2013, as well as $-70 \%$ in Spain between 1980 and 2017) [1]. Consequently, it has been classified as "Near Threatened" within the European countries and "Vulnerable" throughout Africa and Europe, following recent evaluation [2]. Potential factors responsible for the species' decline include breeding habitat degradation [3], reduction of food availability due to agricultural intensification $[4,5]$, hunting, and variation in ecological conditions throughout the migration flyway [5-7].

In Northwestern Africa, the turtle dove is a common breeder and summer migrant [8-10]. It has an important breeding population in Morocco [11], largely dispersed in forest ecosystems $[12,13]$ that represent $12.7 \%$ of the national territory [14] and farmlands representing 1.5\% [11] of the total land area. In agricultural lands, they are more frequent in farm landscapes with irrigated perimeters [10, 15-19], including olive, orange, and apple orchards being particularly favoured [15, 18-20]. Similarly, in Algeria, the turtle dove is distributed over a wide area of the northern part of the country and over the palm oases and groves in the south [21-23]. On the contrary, in Tunisia, where this species is less studied, rare information exists on its breeding and foraging ranges [24].

Most studies of the turtle dove on both European and North African populations have focused on farmland habitats, involving breeding biology [3, 19-22], habitat use [3, 4, 7, 25-28], foraging [4, 18, 29-31], and migration [32-34]. In natural forests, studies were mainly limited to habitat use [27, 35-39] and feeding resources [31, 37]. Moreover, no breeding comparison has been carried out 
between wild and farmland habitats in both Europe and Africa, and this justifies the crucial need to analyse the situation of turtle doves in both woodlands and agricultural habitats.

This study, carried out in the high Moulouya valley at altitudes of 1300-1600 m (Midelt region, Morocco), aims to compare nesting features (nest placement and dimensions) and breeding success of the turtle dove in farmlands (apple orchards) and wild habitats (riparian vegetation) and to identify the most impacting factors of the turtle doves' reproduction in these two types of habitats.

\section{Materials and Methods}

2.1. Study Area. This study was carried out in the upper valley of Moulouya, in Midelt region, located between the Middle Atlas in the northeast and High Atlas Mountains in the north (Figure 1). This area is characterized by a cold arid climate (the annual average temperature and precipitation being about $29^{\circ} \mathrm{C}$ and $89 \mathrm{~mm}$ successively) with a mountainous tendency, and the rainfall regime is marked by high seasonal variations, with low rainfall and stormy precipitation [40, 41].

Two zones were selected for this study: (1) Ansegmir Valley $\left(32^{\circ} 38^{\prime} 20.29^{\prime \prime} \mathrm{N}, 4^{\circ} 59^{\prime} 26.89^{\prime \prime} \mathrm{W}\right)$, in Ait Ayach area, at the foot of the El Ayachi Mountain, and (2) Tabelkhirt Valley $\left(32^{\circ} 42^{\prime} 29.28^{\prime \prime} \mathrm{N}, 5^{\circ} 7^{\prime} 10.10^{\prime \prime} \mathrm{W}\right)$ in Imzil area. Twenty apple orchards were selected as farmlands (Ait Ayach and Moulouya), and eighteen line transects were selected at Ansegmir and Tabelkhirt rivers. Moreover, apple orchards and riparian habitats were selected jointly to avoid any potential difference in climate conditions or geographic location that could influence our nesting parameters, and this will allow a better comparison between the two sites.

2.2. Data Collection. We systematically searched for nests from early March to late August between 2015 and 2018, using parental behavioural cues and Common Bird Census (CBC) methodology [42]. In our case, this methodology was adopted inside apple orchards, where nests or breeding pairs were actively searched along the whole tree lines of the apple orchards [19]. In the riparian vegetation, we used line transects [18], and nests were searched side by side of the river banks. These prospections were carried out during the nest construction period, generally between $06: 00 \mathrm{~h}$ and 18:00 h. To determine the laid eggs, hatched nestlings, and survived chicks, each nest was visited weekly until it failed or chicks fledged. Moreover, breeding success, including hatched egg's rate $(100 \times$ hatched eggs/all laid eggs $)$ and flying chick's rate $(100 \times$ chicks leaving their nests/fledged chicks), was calculated in percentage [10]. In parallel, along with each breeding season, failure factors were recorded, based on carcasses and other signs, such as the status of the nest and feathers inside or outside the nest. Moreover, after chicks leave, each nest was characterized, in terms of placement, including nesting tree, nest height $(\mathrm{NH})$, and nesting-tree height (NTH), as well as in terms of dimensions (big diameter-NBD and small diameter-NSD) and nest depth (ND). Furthermore, the location of each nesting tree was referenced using a mobile GPS and then reported in open-source GIS (Quantum GIS v1.7.3). Finally, distances between dove's nests and the nearest human farms (mainly cereals), the nearest water source, and the nearest road were measured with QGIS in order to explain any potential difference in studied parameters.

2.3. Statistical Tools. Statistical analyses were performed in Statgraphics Centurion software, version XVI. I. Before running the statistical analysis, we checked for normality and homogeneity of variance for all variables with the Kolmogorov-Smirnov test. To assess differences in nest placement and dimension between orchards and riparian sites, we used the independent $t$-test, considering the two sites as unrelated ecosystems. Similarly, breeding success, including nesting, laying, and fledging survival, was analysed with the $t$-test. In addition, correlations among nest placement and nest dimension parameters were tested with Pearson's correlation coefficient. Results were given as sample size and mean \pm SD.

In order to investigate the relevance of distance to neighboring human farms (cereals), to neighboring water plants, to neighboring nests (of other turtle doves), and to neighboring roads as predictors of fledging probability (response variables: 0 (no fledglings produced by eggs' predation or nest abandonment) and 1 (at least one fledgling produced)), a model with a binomial error structure and log it link function was applied.

\section{Results}

3.1. Nest Placement and Dimensions. During the whole study period (2015 to 2018), a total of 566 turtle dove nests were found, among which 467 were only in apple orchards and 99 in diverse riparian supports. In fact, 55 nests were found on wild rose (Rosa canina), 37 nests on hawthorn (Crataegus azarolus), three on Tamarix sp., one on Salix sp., one on poplar, and one on blackberry (Rubus fruticosus) (Figure 2).

The $t$-tests conducted on nest placement characteristics of turtle dove Streptopelia turtur showed that the nest height $(\mathrm{NH})$ and the nesting-tree height $(\mathrm{NTH})$ were similar between orchards and riparian breeding habitats (Table 1). On the contrary, the nest dimensions (NBD and NSD) were significantly larger in orchards compared to those in riparian habitats, while the nest depth was the same in the two habitats.

Correlation was variable among nest placement parameters (nest height and nesting-tree height) and nest dimensions (nest big diameter, nest small diameter, and nest depth) in studied habitats (Table 2). At riparian sites, the NSD and the NBD were significantly correlated, as well as the NSD and ND parameters, while at orchard habitats, only NSD and NH were significantly correlated, as well as $\mathrm{NH}$ and NTH. On the contrary, the other parameters were uncorrelated at both studied habitats.

3.2. Breeding Success. We recorded a total of 566 turtle dove nests during the entire three years between 2015 and 2018 . Among the monitored nests (Table 3), only $73.87 \%$ were 


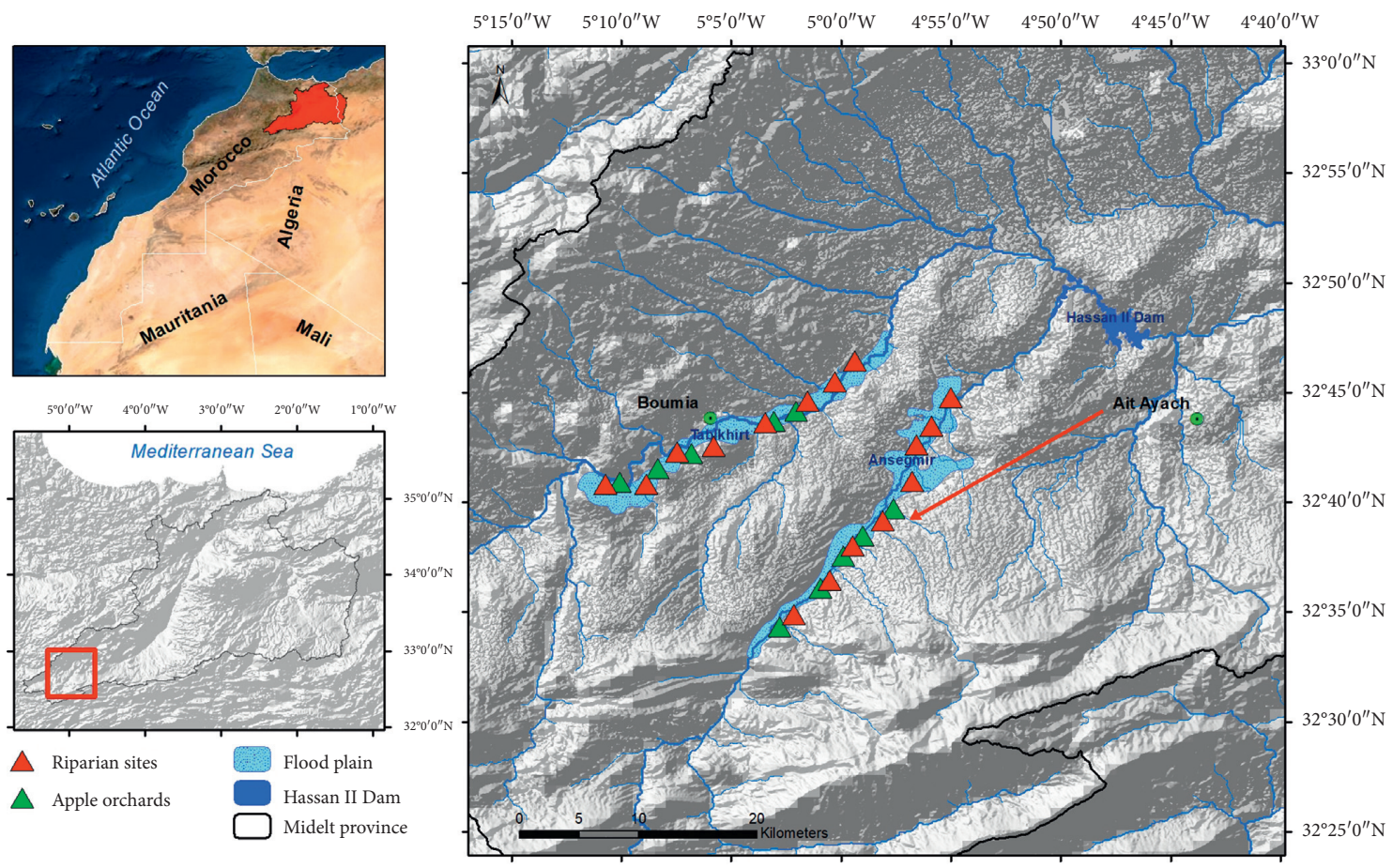

Figure 1: Breeding habitats of the turtle dove in orchards and riparian habitats in Midelt province (Morocco).

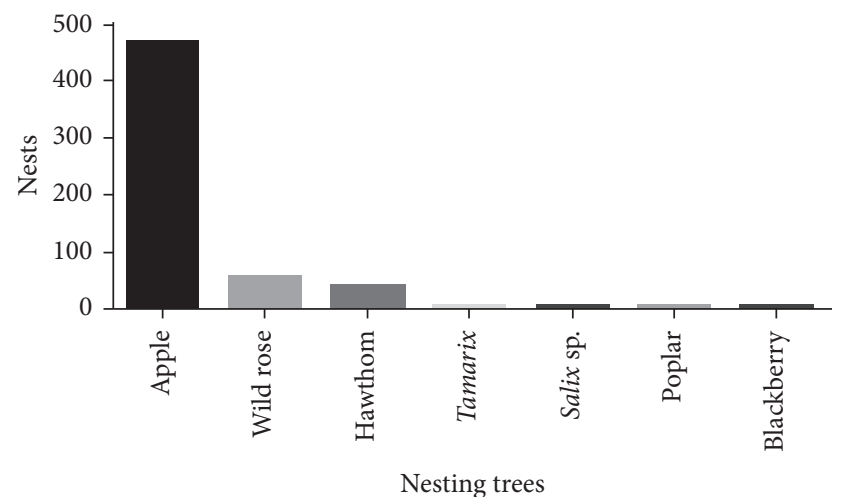

FIGURE 2: Nesting trees used by turtle doves in both farmlands and riparian sites.

TABle 1: Comparisons of nest placement parameters and nest dimensions of turtle doves between apple orchards and riparian habitats, tested using $t$-tests.

\begin{tabular}{lcccc}
\hline & \multicolumn{2}{c}{ Habitat } & \multicolumn{2}{c}{ Test } \\
& Orchards & Rivers & $t$ & $P$ \\
\hline NTH & $4.52 \pm 0.94$ & $4.56 \pm 1.17$ & 0.114 & 0.910 \\
NH & $2.44 \pm 0.51$ & $2.17 \pm 1.07$ & -1.016 & 0.316 \\
NBD & $16.23 \pm 1.72$ & $14.10 \pm 1.84$ & -3.774 & 0.001 \\
NSD & $12.58 \pm 2.05$ & $11.43 \pm 1.25$ & -2.134 & 0.039 \\
ND & $4.79 \pm 1.24$ & $4.20 \pm 1.152$ & 1.535 & 0.133 \\
\hline
\end{tabular}

succeeded at orchards, compared to $53.35 \%$ at riparian habitats. During the incubation phase, fledging success was higher in orchards, compared with river vegetation. However, during the rearing period, the success rates were the same in the two sites. Failure factors were also variable between these habitats. In orchard habitats, predation, nest abandonment, and nonhatching presented the most threats menacing turtle dove breeding success, while in riparian sites, predation, nest desertion, and nest destruction dominated all failed clutches.

In riparian habitats, broods located at longer distance from human farms, mainly cereals, are less likely to produce fledglings. The fledging probability significantly increased as distance to water plants or roads was longer. No relationship was found between fledging probability and distance separating broods to neighboring nests (Table 4), while in orchards, all analysed factors were not influencing breeding success because nests were recorded inside human farms, and water sources were a few meters or less inside apple farms (irrigation systems of farms).

\section{Discussion}

In the Mediterranean region, the turtle dove uses mostly farmlands (olive, orange, apple trees, etc.) as breeding sites $[10,11,19]$; but, this bird has also more or less preference for different native trees as the nesting support. The riparian vegetation was only recently revealed as favourable breeding habitat for the turtle dove in Italy [43]. Our findings confirm the results of this study and provide comparison between farmlands and woodlands as breeding habitats for this bird.

The abundance of nesting trees (apples in orchards and wild rose, Salix, and Tamarix in river banks) and water sources (irrigated orchards and stream water) and the availability of large cereal fields [11] explain the high incidence of nesting turtle doves in these both habitats [18, 41]. Nevertheless, the fact that the nesting incidence of doves is higher in orchards than in riparian sites does not indicate a 
TABle 2: Pearson's correlation coefficients among nest placement characteristics and dimensions of the turtle dove in orchard and riparian habitats.

\begin{tabular}{|c|c|c|c|c|c|c|c|c|c|c|c|}
\hline & & Ripar & labitat & & & & & Orch & habitat & & \\
\hline & NBD & ND & $\mathrm{NH}$ & NSD & NTH & & NBD & ND & NH & NSD & $\mathrm{NTH}$ \\
\hline NBD & - & 0.021 & -0.08 & 0.73 & 0.34 & NBD & - & 0.01 & 0.25 & 0.35 & 0.21 \\
\hline $\mathrm{P}$ & - & 0.92 & 0.70 & 0.001 & 0.13 & & - & 0.96 & 0.27 & 0.11 & 0.35 \\
\hline ND & 0.02 & - & 0.03 & 0.513 & 0.02 & ND & 0.01 & - & 0.44 & 0.36 & 0.09 \\
\hline $\mathrm{P}$ & 0.92 & - & 0.86 & 0.025 & 0.91 & & 0.96 & - & 0.05 & 0.10 & 0.68 \\
\hline $\mathrm{NH}$ & -0.08 & 0.03 & - & -0.07 & 0.37 & $\mathrm{NH}$ & 0.25 & 0.44 & - & 0.52 & 0.57 \\
\hline $\mathrm{P}$ & 0.70 & 0.86 & - & 0.74 & 0.10 & & 0.27 & 0.05 & - & 0.022 & 0.011 \\
\hline NSD & 0.73 & 0.51 & -0.07 & - & 0.24 & NSD & 0.35 & 0.36 & 0.52 & - & 0.24 \\
\hline $\mathrm{P}$ & 0.001 & 0.025 & 0.74 & - & 0.27 & & 0.11 & 0.10 & 0.022 & - & 0.28 \\
\hline $\mathrm{NTH}$ & 0.34 & 0.02 & 0.37 & 0.24 & - & NTH & 0.21 & 0.09 & 0.57 & 0.24 & - \\
\hline $\mathrm{P}$ & 0.13 & 0.91 & 0.10 & 0.27 & - & & 0.35 & 0.68 & 0.011 & 0.28 & - \\
\hline
\end{tabular}

NBD: nest big diameter; NSD: nest small diameter; ND: nest depth; NH: nest height; NTH: nesting-tree height; P: $P$ value.

TABLE 3: Turtle dove's breeding success at orchards ( $n=20$ apple orchards) and riparian vegetation ( $n=18$ riparian sites) tested with a simple $t$-test.

\begin{tabular}{|c|c|c|c|c|c|c|c|}
\hline \multirow[b]{2}{*}{ Phase } & \multirow[b]{2}{*}{ Parameter } & \multicolumn{2}{|c|}{ Orchards } & \multicolumn{2}{|c|}{ Riparian } & \multicolumn{2}{|c|}{ Test } \\
\hline & & Number & $\%$ & & $\%$ & $t$ & $P$ \\
\hline \multirow{5}{*}{ Nests } & Total & 467 & 100 & 99 & 100.00 & \multirow{5}{*}{$1.1748 E+16$} & \multirow{5}{*}{0.001} \\
\hline & Succeeded & 345 & 73.87 & 53 & 53.35 & & \\
\hline & Predated & 98 & 20.98 & 27 & 27.27 & & \\
\hline & Deserted & 24 & 5.14 & 18 & 18.18 & & \\
\hline & Destructed & 0 & 0 & 1 & 1.01 & & \\
\hline \multirow{6}{*}{ Eggs } & Total & 635 & 100 & 184 & 100.00 & \multirow{6}{*}{$8.5267 E+14$} & \multirow{6}{*}{0.001} \\
\hline & Succeeded & 455 & 71.16 & 125 & 67.93 & & \\
\hline & Predated & 120 & 18.89 & 36 & 19.56 & & \\
\hline & Deserted & 28 & 4.41 & 22 & 14.13 & & \\
\hline & Destructed & 0 & 0 & 1 & 0.54 & & \\
\hline & Unhatched & 32 & 5.03 & 0 & 0.00 & & \\
\hline \multirow{5}{*}{ Chicks } & Total & 455 & 100 & 125 & 100.00 & \multirow{5}{*}{$1.2796 E+14$} & \multirow{5}{*}{0.001} \\
\hline & Succeeded & 362 & 79.56 & 99 & 79.20 & & \\
\hline & Predated & 48 & 10.54 & 17 & 13.60 & & \\
\hline & Died & 25 & 5.49 & 0 & 0.00 & & \\
\hline & Deserted & 20 & 4.39 & 9 & 7.20 & & \\
\hline
\end{tabular}

TABLE 4: The effect of distance separating the broods to neighboring human farms, water, nests, or roads on the probability to produce fledgings.

\begin{tabular}{|c|c|c|c|c|}
\hline & Estimate & Standard error & Wald test & $P$ \\
\hline Intercept & -1.073 & 0.530 & 4.101 & 0.043 \\
\hline Distance to human cereals & -0.118 & 0.038 & 9.523 & 0.002 \\
\hline Distance to water sources & 0.063 & 0.028 & 4.991 & 0.025 \\
\hline Distance to nests of other doves & -0.001 & 0.002 & 0.525 & 0.469 \\
\hline Distance to roads & 0.116 & 0.036 & 10.153 & 0.001 \\
\hline Scale & 1.000 & 0.000 & & \\
\hline
\end{tabular}

particular attraction, but reflects, particularly, their abundance (apples) in the study area in comparison with lessabundant riparian vegetation $[18,19,41]$.

The use of high nest placement and taller nesting trees by the species, in both orchards and riparian vegetation, ensures a better protection of its nestling from ground threats (terrestrial predators and human disturbance), mainly in farmlands [19]. Indeed, the nest height is reported to promote greater breeding success of turtle doves in different North African habitats, including Morocco and Algeria [19, 44, 45]. Therefore, turtle doves select taller nesting trees mainly to elevate their nest placement [35]. On the contrary, nests are particularly large in orchards, similar to the results reported in olives in Northwest Algeria [45], with, however, more nest variations depending on habitat types. More generally, a high variability in nest morphology was noted [46] depending on available nesting materials, which are suggested in our study to be the main factor controlling the difference observed in nest morphology.

Our monitoring showed, in the four breeding seasons, different breeding success rates in farmlands and riparian 
habitats (Table 2). In summary, $73.87 \%$ of nests, $71.16 \%$ of eggs, and $79.56 \%$ of chicks survived in orchards, while only $53.35 \%$ of nests, $67.93 \%$ of eggs, and $79.20 \%$ of chicks succeeded in riparian sites. In total, $57 \%$ of chicks (flown chicks/laid eggs) survived in apple orchards compared to $53.80 \%$ in riparian sites. Even the low difference recorded between the two sites is probably due to human disturbances and food availability. Indeed, the riparian sites are highly frequented by humans and motorized engines, in relation with the intensification of irrigated agriculture on the river banks. In apple orchards, the breeding period of the turtle dove (April to August) does not coincide with a high human presence (which is in August and September), making the breeding success of the species even greater than in orange groves [10, 19].

The major factor of breeding failure was predation in both types of sites, mainly by reptiles. However, in the relatively cold region of Midelt, low spring temperatures seem to be another significant factor, as it was responsible for $5.03 \%$ unhatched eggs and $5.45 \%$ dead chicks in orchards. On the contrary, the model with a binomial error structure indicated differences in the habitat features affecting breeding success, mainly in riparian habitats. Long distance separating breeding habitats on rivers with foraging (food and water) had a higher probability of nest failure (death of broods due to lack of sufficient food resources), while closer roads to breeding sites have intensified failures, mainly by the disturbance of breeder doves. On the contrary, breeding sites on orchards were inside cereals and surrounded by irrigation systems (availability of water), and these promote breeding success $[20,36,44]$.

\section{Conclusion}

In summary, our study demonstrates that nesting features and breeding success of the migrant turtle dove differed between farmlands and natural woodlands. Nest placement is the same in the two habitat types, while nests were larger in apple orchards. Similarly, the breeding success rates were different as nesting, hatching, and fledging rates were higher in apple orchards. In addition, clutches failed due to predation and rough morning temperatures in orchards, while predation and desertion were the main factors of clutch failure in riparian habitats.

Additional studies of microfactors influencing breeding performances of turtle doves in both farmlands and woodlands are required to further explore the difference between natural and artificial habitats used by this globally vulnerable game. Similarly, the use of novel techniques, including telemetry and geolocation, will improve our understanding of the habitat use in both farmlands and wild habitats, particularly with the capacity of these tools to monitor all activity details inside and outside nesting sites. In this context, we planned a new monitoring that aims to clarify the relationship between chick death and temperature lowering in spring season, with expectation to more deeply investigate microclimate effects on the breeding performances of turtle dove.

\section{Data Availability}

The data used to support the findings of this study are included within the article.

\section{Conflicts of Interest}

The authors declare that they have no conflicts of interest.

\section{Acknowledgments}

The authors are grateful to Ait Ayach farmers for their help on the field work and data collection.

\section{References}

[1] J. C. Dunn, J. E. Stockdale, R. J. Moorhouse-Gann et al., "The decline of the Turtle Dove: dietary associations with body condition and competition with other columbids analysed using high-throughput sequencing," Molecular Ecology, vol. 27, no. 16, pp. 3386-3407, 2018.

[2] Birdlife International, Streptopelia turtur. The IUCN Red List of Threatened Species, Birdlife International, Cambridge, UK, 2015.

[3] S. Browne, N. Aebischer, G. Yfantis, and J. Marchant, "Habitat availability and use by turtle doves Streptopelia turtur between 1965 and 1995: an analysis of common birds Census data," Bird Study, vol. 51, pp. 1-11, 2004.

[4] S. J. Browne and N. J. Aebischer, "Temporal changes in the breeding ecology of European Turtle Doves Streptopelia turtur in Britain, and implications for conservation," Ibis, vol. 146, no. 1, pp. 125-137, 2003.

[5] C. Eraud, J.-M. Boutin, M. Riviere, J. Brun, C. Barbraud, and H. Lormée, "Survival of Turtle DovesStreptopelia turturin relation to western Africa environmental conditions," Ibis, vol. 151, no. 1, pp. 186-190, 2009.

[6] S. Hidalgo de Trucios, Management Plan for Turtle Dove (Streptopelia turtur) 2007-2009, European Communities, Brussels, Belgium, 2007.

[7] S. Browne and N. Aebischer, "The role of agricultural intensification in the decline of the turtle dove Streptopelia turtur," English Nature Research Report No 421, English Nature, Peterborough, CA, USA, 2001.

[8] M. Thevenot, R. Vernon, and P. Bergier, The Birds of Morocco. British Ornithologists' Union/British Ornithologists'Club, Tring, UK, British Ornithologists' Union/British Ornithologists'Club, Tring, UK, 2003.

[9] P. Isenmann, Oiseaux de Libye/Birds of Libya, Société d'Etudes Ornithologiques de France (SEOF), Paris, France, 2016.

[10] I. Mansouri, M. Mounir, W. Squalli, L. Elhanafi, M. Dakki, and L. El Ghadraoui, "Migratory dates, breeding phenology, and reproductive success of European turtle doves between lowlands and highest breeding habitats in north Africa," International Journal of Zoology, vol. 21, 2020.

[11] S. Hanane, "The European turtle-DoveStreptopelia turturin northwest Africa: a review of current knowledge and priorities for future research," Ardeola, vol. 64, no. 2, pp. 273-287, 2017.

[12] S. Hanane, "Suivi de la reproduction de la tourterelle des bois (Streptopelia turtur) dans la région de Taroudant au cours de l'année 2002. Rapport, Département des Eaux et Forêts et à la Lutte Contre la Désertification," European Journal Of Ecology, vol. 19, 2003.

[13] S. I. Cherkaoui, M. Dakki, R. I. Hamid, and M. Thévenot, "Birds of Cork Oak forest of Ma'amora (Morocco): 
phenology, status of breeding species and evolution since the beginning of the 20th century," Alauda, vol. 75, pp. 15-32, 2007.

[14] O. Mhirit and P. Blerot, Le grand livre de la forêt marocaine. Editions Mardaga, Mardaga Pierre, Dublin, OH, USA, 1999.

[15] S. Hanane and L. Baamal, "Are Moroccan fruit orchards suitable breeding habitats for Turtle DovesStreptopelia turtur?" Bird Study, vol. 58, no. 1, pp. 57-67, 2011.

[16] S. Hanane, "Effects of location, orchard type, laying period and nest position on the reproductive performance of Turtle Doves (Streptopelia turtur) on intensively cultivated farmland," Avian Research, vol. 7, no. 1, p. 4, 2016.

[17] S. Hanane, "Effects of orchard type and breeding period on Turtle Dove nest density in irrigated agroecosystems," Bird Study, vol. 63, no. 1, pp. 141-145, 2016.

[18] I. Mansouri, M. K. Al-Sadoon, M. Rochdi, B. A. Paray, M. Dakki, and L. Elghadraoui, "Diversity of feeding habitats and diet composition in the turtle doves Streptopelia turtur to buffer loss and modification of natural habitats during breeding season," Saudi Journal of Biological Sciences, vol. 26, no. 5, pp. 957-962, 2019.

[19] I. Mansouri, D. Ousaaid, W. Squalli, H. Sqalli, L. E. Ghadraoui, and M. Dakki, "The turtle dove (Streptopelia turtur) in Midelt plain, Morocco: nesting preferences and breeding success versus the impact of predation and agricultural practices," Journal of Animal Behaviour and Biometeorology, vol. 8, no. 3, pp. 206-214, 2020.

[20] A. EL Hassani, M. Dakki, and L. El Ghadraoui, "Chronologie de la reproduction de la Tourterelle des bois Streptopelia turtur arenicola dans la région de Taroudant (Maroc)," Bulletin de l'Institut Scientifique, Rabat, Section Sciences de la Vie, vol. 40, pp. 11-22, 2018.

[21] K. Yahiaoui, K. Arab, M. Belhamra, S. J. Browne, J.-M. Boutin, and A. Moali, "Habitat de la Tourterelle des bois (Streptopelia turtur) dans la vallée d'Isser," Revue d Ecologie, vol. 69, 2014.

[22] K. Absi, M. Belhamra, Y. Farhi, and Y. Halis, "A comparison of the reproduction of collareddoves Streptopelia decaocto and turtle doves Streptopelia turtur in the Ziban Oases (Biskra, Algeria)," Journal of Entomology and Zoology Studies, vol. 3, no. 2, pp. 286-289, 2015.

[23] S. Nasrine, S. Hanane, F. Kamilia, and M. D. E. H. Khemis, "Nest age as predictor of nest survival in three sympatric dove species breeding in a mediterranean arid agroecosystem," Ardea-Wageningen, vol. 108, 2020.

[24] J. Boukhriss, S. Selmi, and S. Nouira, "Bird nest predation in a southern Tunisian oasis habitat: No evidence of "edge effect"" Acta Oecologica, vol. 35, no. 2, pp. 174-181, 2009.

[25] S. J. Browne, N. J. Aebischer, and H. Q. P. Crick, "Breeding ecology of Turtle DovesStreptopelia turturin Britain during the period 1941-2000: an analysis of BTO nest record cards," Bird Study, vol. 52, no. 1, pp. 1-9, 2005.

[26] J. C. Dunn, A. J. Morris, and P. V. Grice, "Post-fledging habitat selection in a rapidly declining farmland bird, the European turtle dove Streptopelia turtur," Bird Conservation International, vol. 27, no. 1, p. 45, 2016.

[27] D. E. Bakaloudis, C. G. Vlachos, E. Chatzinikos, V. Bontzorlos, and M. Papakosta, "Breeding habitat preferences of the turtledove (Streptopelia turtur) in the Dadia-Soufli National Park and its implications for management," European Journal of Wildlife Research, vol. 55, no. 6, pp. 597-602, 2009.

[28] J. C. Dunn and A. J. Morris, "Which features of UK farmland are important in retaining territories of the rapidly declining Turtle DoveStreptopelia turtur?" Bird Study, vol. 59, no. 4, pp. 394-402, 2012.
[29] G. Rocha and P. Quillfeldt, "Effect of supplementary food on age ratios of European turtle doves (Streptopelia turtur L.)," Animal Biodiversity and Conservation, vol. 38, 2015.

[30] A. Gutiérrez-Galán and C. Alonso, "European turtle dove Streptopelia turtur diet composition in southern Spain: the role of wild seeds in mediterranean forest areas," Bird Study, vol. 63 , no. 4 , pp. 1-10, 2016.

[31] A. Gutierrez-Galan, A. L. Sanchez, and C. A. GonzáLez, "Foraging habitat requirements of European turtle dove Streptopelia turtur in a mediterranean forest landscape," Acta Ornithologica, vol. 53, no. 2, pp. 143-154, 2019.

[32] C. Eraud, M. Rivière, H. Lormée, J. W. Fox, J.-J. Ducamp, and J.-M. Boutin, "Migration routes and staging areas of transsaharan turtle doves appraised from light-level geolocators," PloS one, vol. 8, no. 3, Article ID e59396, 2013.

[33] H. Lormee, J.-M. Boutin, D. Pinaud, H. Bidault, and C. Eraud, "Turtle Dove Streptopelia turtur migration routes and wintering areas revealed using satellite telemetry," Bird Study, vol. 63 , no. 3, pp. 425-429, 2016.

[34] M. Marx, F. Korner-Nievergelt, and P. Quillfeldt, "Analysis of ring recoveries of European turtle DovesStreptopelia turturflyways, migration timing and origin areas of hunted birds," Acta Ornithologica, vol. 51, no. 1, pp. 55-70, 2016.

[35] S. Hanane, "Nest-niche differentiation in two sympatric Streptopelia species from a North African agricultural area: the role of human presence," Ecological Research, vol. 30, no. 4, pp. 573-580, 2015.

[36] S. Hanane and M. Yassin, "Nest-niche differentiation in two sympatric columbid species from a Mediterranean Tetraclinis woodland: considerations for forest management," Acta Oecologica, vol. 78, pp. 47-52, 2017.

[37] J. Dunn, A. Morris, P. Grice, and W. Peach, "Effects of seedrich habitat provision on territory density, home range and breeding performance of European turtle doves," Bird Conservation International, vol. 202020 pages, 2020.

[38] L. Moreno-Zarate, A. Estrada, W. Peach, and B. Arroyo, "Spatial heterogeneity in population change of the globally threatened European turtle dove in Spain: the role of environmental favourability and land use," Diversity and Distributions, vol. 26, no. 7, pp. 818-831, 2020.

[39] J. L. Tellería, R. Carbonell, G. Fandos et al., "Distribution of the European turtle dove (Streptopelia turtur) at the edge of the South-Western Palaearctic: transboundary differences and conservation prospects," European Journal of Wildlife Research, vol. 66, no. 5, p. 74, 2020.

[40] A. Giuliani, S. Mengel, C. Paisley et al., "Realities, perceptions, challenges and aspirations of rural youth in dryland agriculture in the Midelt province, Morocco," Sustainability, vol. 9, no. 6, p. 871, 2017.

[41] I. Mansouri, “"The first survey of European serinchick's growth under natural conditions: which organs get maturity before nest leaving," Research Journal of Pharmaceutical Biological and Chemical Sciences, vol. 9, no. 5, pp. 64-73, 2018.

[42] J. Calladine, F. Buner, and N. J. Aebischer, "Temporal variations in the singing activity and the detection of Turtle DovesStreptopelia turtur: implications for surveys," Bird Study, vol. 46, no. 1, pp. 74-80, 2010.

[43] G. Chiatante, Z. Porro, and A. Meriggi, "The importance of riparian forests and tree plantations for the occurrence of the European Turtle Dove Streptopelia turtur in an intensively cultivated agroecosystem," Bird Conservation International, vol. 202015 pages, 2020.

[44] S. Hanane, "Plasticity in nest placement of the turtle dove (Streptopelia Turtur): experimental evidence from Moroccan 
agro-ecosystems," Avian Biology Research, vol. 7, no. 2, p. 65, 2014.

[45] H. Brahmia, A. Zeraoula, T. Bensouilah, Z. Bouslama, and M. Houhamdi, "Breeding biology of sympatric LaughingStreptopelia senegalensisand TurtleStreptopelia turturDove: a comparative study in northeast Algeria," Zoology and Ecology, vol. 25, no. 3, pp. 220-226, 2015.

[46] W. Squalli, I. Mansouri, M. Dakki, and F. Fadil, "Nesting habitat and breeding success of Fulica atra in tree wetlands in Fez's region, central Morocco," Journal of Animal Behaviour and Biometeorology, vol. 8, no. 4, pp. 282-287, 2020. 